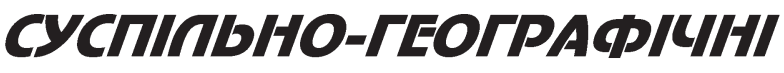 DOCRIOKEHHIG
}

\section{Від редакції}

Питання геоурбаністики, формування та розвитку міського простору традииійно перебувають у колі досліджень географів. Про їх важливість свідчить і створення спеціальної науково-дослідницької групи «Міські простори і мережі» з представників різних країн Свропи. У їі роботі беруть участь і науковиі Інституту географії НАН Украӥни, на базі Інституту у вересні 2013 р. проведено міжнародний науковий семінар «Поліцентризм в Свропейському контексті» за участю 15 іноземних учасників.

«Український географічний журнал» регулярно вмімує публікаџії з географії міст, як стосовно загальних тематично спрямованих питань - міста в умовах неоліберального розвитку суспільства (2012 - № 4), зміни міського простору (2013 - № 2), креативні стратегії розвитку міст (2014 - № 2), міжнародні функиії міст (2014 - № 4) та ін., так і стосовно столищь держав - деценттралізація функиій столичного міста (2012 - № 1), столичі держав - географічні об 'єкти (2014 -№ 4) та ін. Столииі України - м. Київ присвячено статті в УГЖ 2013 -№ 3 та 2015 - № 1. У иььому номері журналу вміщено статті відомих учених Е. Буліно (Франція) стосовно міжнародних зв 'язків міст-побратимів Причорномор'я та Т. Егеді $i$ 3.Ковача (Угорщина) про особливості розвитку Будапешта - столищі Угорщини.

\author{
УДК 911.375:913 \\ doi: 10.15407/ugz2015.02.033
}

\section{Булино Эмманюэль \\ Университет Люмьер Лион-2, Высшая нормальная школа Лиона, Франция
МЕЖДУНАРОДНЫЕ СВЯЗИ ГОРОДОВ-ПОБРАТИМОВ ПРОСТРАНСТВЕННАЯ И ВРЕМЕННАЯ ДИНАМИКА

\author{
Буліно Емманюель \\ Університет Люм'єр Ліон-2, Вища нормальна школа Ліона, Франція \\ МІЖНАРОДНІ ЗВ'ЯЗКИ МІСТ-ПОБРАТИМІВ ПРИЧОРНОМОР'Я: ПРОСТОРОВА І ЧАСОВА ДИНАМІКА
}

У статті досліджуються питання структурування простору Причорномор'я з позицій геополітики, з урахуванням процесів глобалізації та регіоналізму. Ступінь інтернаціоналізації та регіоналізації на локальному рівні визначається на основі вивчення побратимських зв'язків міст Причорномор'я, з розумінням побратимського руху як ініціативи знизу.

Дано визначення поняття «побратимські зв'язки» між містами - традиційне та сформульоване в нових умовах розвитку цього процесу. Основні методи дослідження спрямовані на необхідність вияснення меж прибережних країн Причорномор'я, критеріїв визначення поняття «місто», підходів до створення бази даних. Для аналізу останньої висунуто кілька гіпотез: щодо пропорційності кількості побратимських зв'язків міст їх населенню, стосовно сили впливу розпаду соціалістичної системи, а також ролі просторової близькості. По кожному з цих напрямів отримано конкретні результати. Окреслено також низку невирішених питань, які мають стати темою подальших досліджень.

Ключові слова: місто; міста-побратими; інтернаціоналізація; регіоналізація; глобалізація; Причорномор'я.

\section{Boulineau Emmanuelle}

Lumière University Lyon 2, École Normale Supérieure de Lyon, France

INTERNATIONAL RELATIONS BETWEEN SISTER CITIES IN THE BLACK SEA AREA: SPATIAL AND TEMPORAL DYNAMICS The issues of the Black Sea area structuring from the standpoint of geopolitics and taking in consideration the processes of globalization and regionalism have been researched in the article. The degree of internationalization and regionalization at the local level is defined based on the study of the Black Sea area fraternal relations between cities, understanding twinning movement as initiatives from below.

The definition of sister cities both traditional as well as the one formed under the new conditions of this process development has been given. Main methods of research were directed at the need for clarification of the Black Sea coastal boundaries, criteria for the term «city» definition, approaches to the database creation. To analyze the latter several hypotheses were put forward: proportionality of the sister cities relations number to their population, force of the soviet system collapse impact and the role of spatial proximity. For each of these areas received concrete results. A number of outstanding issues to be the subject of further research has been outlined.

Keywords: city; Sister Cities; internationalization; regionalization; globalization; Black Sea area.

\section{Введение}

Чёрное море находится между Европой и Азией, недалеко от Ближнего Востока и поэтому является своеобразной лабораторией для изучения пространственной динамики глобализации. Мно- гочисленные исследования раскрывают различные аспекты его позиционирования в изменениях мировых процессов. Через Чёрное море проходят интенсивные потоки углеводородов и из-за этого его хинтерланд весьма расширился, что связано 
с введением в строй больших инфраструктурных объектов.

$\mathrm{C}$ точки зрения геополитики, Причерноморье испытало значительные изменения. В этом регионе в 1991 г. распад СССР повлёк за собой появление трёх новых стран, которые непосредственно выходят на побережье Черного моря. В связи с вхождением Болгарии и Румынии в Европейский Союз (ЕС) в 2007 г. его западное побережье было включено в панъевропейские процессы.

Прибрежные страны Чёрного моря находятся в зоне интересов ведущих мировых экономических и геополитических центров. Выход на побережье Чёрного моря Европейского Союза при нерешённости вопроса о включении в его состав Турции весьма усложняет ситуацию, в которой Россия - лидер Евразийского союза видит шанс для изменения геополитической ситуации в данном регионе мира. Такое положение на стыке интересов этих двух гигантов имеет много последствий во внутреннем развитии прибрежных государств.

Такая фрагментация регионального пространства Причерноморья происходит параллельно с усилением глобализационных процессов, которые сопровождаются подписанием многочисленных договоров и соглашений между государствами и ведущими международными организациями. Также следует помнить и о регионализме. Увеличение количества таких соглашений весьма впечатляет: Организация черноморского экономического сотрудничества (1992), Комиссия Черного моря (1992), ГУАМ (1997), Причерноморский форум (2006) и т.д. ЕС также играет существенную роль в регионе посредством заключения ряда соглашений: INOGATE (1995) направлено на партнерство в сфере энергетики, TRACECA (1998) - в сфере транспорта и усиления связей между причерноморскими странами (2007), Восточное партнерство (2009) - в рамках европейской политики соседства.

Таким образом, структуризация региона вокруг Чёрного моря произошла очень быстро, однако при этом отношения между рядом прибрежных государств весьма напряжённые $[10,16,17]$.

В своём исследовании мы изучаем динамику политики на низовом уровне по структурированию пространства Причерноморья в регионе, вовлечённом в мировые процессы. Для этого мы изучаем города-побратимы, как отображение уровня интернационализации региона. Данное исследование было проведено в рамках европейской исследовательской программы ESPON ITAN ${ }^{1}$. Страны, которые соседствуют с ЕС, рассматри-

\footnotetext{
1 Программа научных исследований ESPON ITAN (Integrated territorial analysis of the neighbourhood). Её результаты на английском языке представлены на сайте: http:// www.espon.eu/main/Menu_Projects/Menu_AppliedResearch/ itan.html
}

ваются как страны-соседи. В нашем исследовании изучалась лишь часть таких стран. Россия, Украина, Грузия и Турция рассматриваются в Причерноморье именно как страны-соседи ЕС.

В шести прибрежных странах Причерноморья, которые мы изучали (Болгария, Грузия, Румыния, Россия, Турция и Украина), международная открытость городов фактически произошла в последние десятилетия. В Турции - это период 80-х гг. ХХ ст., в Болгарии и Румынии - после 1989 г., для постсоветского пространства - после 1991 г. Такой огромный город как Истанбул (около 13 млн жителей) давно является международным центром. Другие города-миллионеры, такие как Ростов-на-Дону и Одесса доминируют в региональном пространстве. Большинство городов Причерноморья являются портами, что значительно упрощает международные контакты между ними. Некоторые из них существуют уже несколько столетий.

Интернационализация городов имеет несколько форм. Соревнование между городами в рамках глобализации - лишь одна из них. Территориальное сотрудничество также позволяет построить международные партнёрские связи между городами, причем именно города их и инициируют. Признание городов как автономных участников такого процесса прописано в «Хартии местного самоуправления» Совета Европы, которая вступила в силу в причерноморских странах: в Турции в 1993 г., Болгарии в 1995 г., Румынии, России и Украине в 1998 г., в Грузии в 2007 г. Эти формы интернационализации не исключают одна другую. Побратимские связи указывают на стратегическое измерение уровня конкурентоспособности городов, которые в совершенстве овладевают процессами обмена опытом в рамках такого партнёрства.

Изучение побратимских связей городов Причерноморья позволит таким образом определить степень интернационализации и регионализации на локальном уровне и сопоставить полученные результаты с теми, которые были проведены в вышеупомянутых исследованиях высокой геополитики. Эти работы написаны с европейских позиций западного подхода к побратимскому движению и интернационализации городов. Однако, таковы ли реалии связей на локальном уровне в рамках побратимского движения городов?

\section{Изученность побратимского движения городов: теории, определения и методы}

\section{Определения и теории изучения побратимского движения городов}

Библиография по вопросу побратимского движения городов весьма незначительна по сравнению с литературой по интернационализации городов и их конкуренции. При этом следует учесть, что публикации на английском и французском языках, 
которые мы изучали, представляют европоцентристский подход с позиций неолиберальной парадигмы и англо-саксонской школы изучения городов.

Можно выделить три основных теоретических подхода в данной научной литературе по вопросу побратимского движения городов.

П е р в ы й п о д х о д опирается на парадигму международных отношений. Констатируя все возрастающую интернационализацию городов и соперничество между ними на глобальном уровне, международные отношения изучают побратимское движение городов в рамках «дипломатии городов» («local foreign policies») или же парадипломатии. Возможность государств развивать внешние связи переносится на города в рамках глобализации $[19,20]$. Начиная с 80-х гг. XX ст., начали использовать термин «децентрализованная кооперация», понимая под децентрализацией передачу отдельных сфер компетенции государства, таких как сотрудничество, для их осуществления напрямую городом.

В торой по дход географичен, он указывает на то, что интернационализация городов является особой формой игры масштабов от локального до глобального. Глобализация порождает эффект «глокализации» (соединения терминов «глобализация» + «локализация»), суть которого заключается в том, что при осуществлении локальных действий следует думать в глобальном масштабе.

Одним из ведущих теоретиков данного подхода является британский географ Эрик Свингедоу [18]. В его рамках считается, что побратимское движение городов является способом, с помощью которого города могут перейти на более высокий ранг в мировой иерархии городов (rescaling или же политика масштабов), не забывая при этом о парадигме конкуренции между городами [7, 9]. Побратимское движение городов таким образом становится лишь связью между самими городами, обусловливая тем самым интерес к управлению ними и передаче лучших примеров городского самоуправления от городов Севера городам Юга [2]. Побратимское движение городов таким образом способствует стратегическим альянсам между ними.

Т р е т и й п о д х о д ныне только развивается. В нём акцентируется внимание на локальный уровень, так как необходимо понять интерес в установлении побратимских связей между городами как одной из форм территориальной кооперации. Таким образом, побратимские связи понимаются как один из инструментов привлечения новых знаний и умений, которые можно передать лишь имея одинаковые цели и ценности $[1,21]$. Интернационализация изучается при таком подходе как одна из практик гостеприимства [12], дружбы и добрососедства [8]. Установление побратимства предполагает социальную близость между двумя городами.
В нашем исследовании мы опираемся на понимание побратимского движения городов как инициативы снизу. Такие связи являются модальностью территориального сотрудничества [4]. В многочисленных трудах анализируется трансграничное сотрудничество и еврорегионы именно как формы территориального сотрудничества между ЕС и его странами-соседями. Место городов в мировой динамике предопределяет формы их территориального сотрудничества, которые следует изучать, построение международных сетей городов [3, 11], в которых вопросы побратимского движения городов мало изучены. Побратимские связи не предопределяются заранее, а являются порождением простого знакомства, к тому же они не имеют под собой сильной финансовой подоплёки. Эти слабые связи могут стать сильными, когда они обеспечат городам возможность быть включенными в сеть городов, в рамках которой можно устанавливать связи на других уровнях иерархии городов.

Побратимское движение городов зародилось во времена «холодной войны». Если государства были противниками, то города выступали строителями связей между ними $[5,6]$. После окончания «холодной войны» и появления многополюсного мира регион Причерноморья стал новым местом соперничества и кооперации между странами [14], а побратимские связи между городами отображают новые формы динамики сотрудничества в регионе.

Определение понятия «побратимские связи» между городами взято нами из предложенного CCRE (Советом коммун и регионов Европы): «Побратимские связи - это встреча двух коммун, которые провозглашают своё сотрудничество в рамках европейской перспективы, с иелью совместного решения обших проблем и для развития между ними тесных дружеских связей» (определение Жана Барета, президента CCRE в 1951 г.). Оно является старым и европоцентричным, однако действительно и по сей день. Оно позволяет указать на мотивы установления побратимских связей между городами: совместное решение трудностей; поддержание мира через дружбу; развитие связей между городами. Для исследования Причерноморья это определение является корректным.

Шестьдесят лет спустя было предложено другое определение:

«Побратимское движение городов является одной из форм связей, используемой городами, отличительной чертой которой является создание видимого и благоприятного имиджа городов, и в этом смысле оно является неотъемлемой частью их политики маркетинга и брендинга в контексте все более интенсивной транснациональной регионализации» [13]. Акцентируя внимание на неолиберальной парадигме города, который сам управляет своим развитием, это определение указывает 
на прямое влияние глобализации и на соперничество между городами в рамках побратимского движения. Эти два определения не являются взаимоисключающими, а лишь представляют различные точки зрения на стратегию городского развития.

\section{Методы анализа побратимского движения городов}

Изучение побратимских связей городов Причерноморья требует их рассмотрения с двух сторон. С одной стороны, с геополитических позиций Причерноморье является разделённым пространством. С другой стороны, ускоренное включение в международные потоки (глобализация) и подписание соглашений о сотрудничестве между прибрежными странами (регионализм) указывают на серьёзные территориальные изменения.

Изучение побратимского движения городов ставит вопрос о региональной интеграции через построение связей снизу. Мы опираемся на методологию европейской программы ESPON TERCO², в рамках которой изучались побратимские связи городов ЕС. Однако, не следует забывать и о специфике Причерноморья.

Во-первых, необходимо уяснить грани цы приб режных с т ран Причерноморья. Шесть стран, среди которых такие обширные по площади страны как Россия и Турция, предполагают установление границ прибрежных регионов. Определение Евростата основано на территориально-административном делении ЕС и поэтому его легко применить к странам вне ЕС. Ими являются «статистические регионы уровня NUTS3, более половины населения которых проживает на расстоянии менее 50 км от берега моря». Уровню NUTS3 соответствуют регионы (области) в Болгарии, департаменты (жудецьь) в Румынии, провинции (ил) в Турции согласно номенклатуре ЕС. В России это край, в Украине - область, в Грузии - автономные республики и края (мхаре).

Во-вторых, нужно установить к р и т е р и и о п реде ле ния поня тия «город»: в каждой из стран они свои. Как видно из табл. 1, сравнение основных международных показателей города свидетельствует о том, что они весьма поразному представлены в каждой из данных стран, что обусловлено их историческим развитием.

В России, Украине и Грузии понятие «город» прежде всего политическое: оно определяется государственной властью и дополнено демографическим и функциональным критериями (превалирование среди населения занятых в несельскохозяйственных видах деятельности). Этот поли-

${ }^{2}$ ESPON TERCO http://www.espon.eu/main/Menu_ Projects/Menu_AppliedResearch/terco.html
Таблица 1. Сравнение определения «город» в шести странах Причерноморья

\begin{tabular}{|l|c|c|c|c|}
\hline \multicolumn{1}{|c|}{ Страна } & $\begin{array}{c}\text { Полити- } \\
\text { ческий } \\
\text { статус }\end{array}$ & $\begin{array}{c}\text { Числен- } \\
\text { ность } \\
\text { населения }\end{array}$ & $\begin{array}{c}\text { Городская } \\
\text { морфо- } \\
\text { логия }\end{array}$ & $\begin{array}{c}\text { Экономи- } \\
\text { ческие } \\
\text { функции }\end{array}$ \\
\hline Болгария & $\mathbf{X}$ & & & \\
\hline Румыния & $\mathbf{X}$ & & & \\
\hline Украина & $\mathbf{X}$ & $\mathbf{X}$ & & $\mathbf{X}$ \\
\hline Россия & $\mathbf{X}$ & $\mathbf{X}$ & & $\mathbf{X}$ \\
\hline Грузия & $\mathbf{X}$ & $\mathbf{X}$ & & $\mathbf{X}$ \\
\hline Турция & $\mathbf{X}$ & $\mathbf{X}$ & & \\
\hline
\end{tabular}

Составлено по данным Демографического ежегодника ООН (2005).

тический статус могут иметь различные типы поселений в рамках административной иерархии центров управления административно-территориальными единицами.

В Болгарии и Румынии определение города является исключительно политическим решением, без какого-либо демографического или функционального критерия.

В Румынии города имеют различный статус, что связанно с предоставлением им различных сумм субвенций для местных бюджетов. В Турции определение города - также политическое решение, которое связано с демографическим критерием, обусловленным местом в иерархии центров административно-территориальных единиц страны.

Таким образом, определение города во всех странах является прежде всего политическим актом, он является единицей административно-территориального устройства, которая имеет своего главу и городской совет. Это позволяет городу самостоятельно устанавливать и осуществлять побратимские связи. Следовательно, наделение города определенным политическим статусом является весьма важным.

Изучение демографического критерия города и установление его нижней границы весьма важно, ибо это позволяет исключить из исследования малые города, не играющие существенной роли в побратимском движении. Международные исследования по данному вопросу указывают на целесообразность принятия в качестве нижней границы людность города в 10 тыс. чел. Этот критерий установлен в базе данных «E-geopolis» ${ }^{3}$ и принят при сравнении городов мира за длительный период [15]. Принятие данного критерия позволяет избегнуть сложного вопроса об отличии между городским пространством и сельской местностью.

В-третьих, необходимо создать б а з у д а н н ы х по побратимским связям, составить спис-

${ }^{3} \mathrm{http}: / / \mathrm{e}-$ geopolis.eu/?lang=en 
Таблица 2. Характеристика показателей базы данных по побратимским связям городов Причерноморья

\begin{tabular}{|l|c|c|c|c|c|c|c|}
\hline \multicolumn{1}{|c|}{ Страна } & $\begin{array}{c}\text { Городское } \\
\text { население } \\
\text { страны в } \\
\text { Причерно- } \\
\text { морском } \\
\text { регионе }\end{array}$ & $\begin{array}{c}\text { Количество } \\
\text { городов, } \\
\text { которые } \\
\text { имели } \\
\text { побратим- } \\
\text { ские связи }\end{array}$ & $\begin{array}{c}\text { Коли- } \\
\text { пество } \\
\text { ских } \\
\text { связей }\end{array}$ & $\begin{array}{c}\text { Количество } \\
\text { стран, с } \\
\text { городами } \\
\text { которых были } \\
\text { установлены } \\
\text { побратимские } \\
\text { связи }\end{array}$ & $\begin{array}{c}\text { Среднее } \\
\text { число } \\
\text { побратим- } \\
\text { ских связей на } \\
\text { один город } \\
\text { страны }\end{array}$ & $\begin{array}{c}\text { Среднее } \\
\text { число } \\
\text { побратим- } \\
\text { ских связей одного } \\
\text { жителя города } \\
\text { писло } \\
\text { побратим- } \\
\text { ских } \\
10 \text { тыс. } \\
\text { жителей }\end{array}$ & $\begin{array}{c}\text { Среднее } \\
\text { Болгария }\end{array}$ \\
\hline Грузия & 414545 & 9 & 67 & 29 & 7,4 & 10380 & 9,6 \\
\hline Румыния & 530298 & 6 & 46 & 23 & 7,2 & 10111 & 9,9 \\
\hline Россия & 3959364 & 16 & 86 & 30 & 5,4 & 46039 & 2,2 \\
\hline Турция & 17022454 & 39 & 181 & 60 & 4,6 & 94047 & 1,1 \\
\hline Украина & 6735837 & 24 & 178 & 39 & 7,4 & 37842 & 2,6 \\
\hline Всего & 29357951 & 99 & 599 & 80 & 6,1 & 49012 & 2,0 \\
\hline
\end{tabular}

Составлено на основе базы данных побратимских связей городов

ки городов-побратимов. В нашем исследовании побратимские/партнерские связи между городом и другой единицей административно-территориального деления (регионом, департаментом и т.д.) не были включены, а также не были включены побратимские связи между городами одной страны. Мы использовали метод сбора данных, принятый в программе ESPON TERCO, - проверка соответствующих страниц, посвященных городам Причерноморья, в «Wikipedia» по поводу установления их городов-побратимов. Для удобства сравнения между странами мы взяли список стран, предложенный на английской версии данного сайта, что позволило не изменять его всякий раз при посещении страниц на других языках. В базе данных указано название города-побратима, страна и, в большинстве случаев, дата установления побратимства. Однако столь краткая информация о городах-побратимах не позволяет установить, являются ли такая связь активной или же она больше не существует в реальности.

Этот первый список был в последствии использован при подведение итогов по странам и перепроверен по страницам «Wikipedia» на языке каждой из стран, потом были изучены веб-сайты городов (главным образом веб-страницы, посвященные их внешним связям) и существующие соответствующие национальные базы данных (в Болгарии и Турции), а в конце - международные базы данных по побратимским связям городов ЕС (база данных Совета коммун и регионов Европы $\left.{ }^{4}\right)$.

Работа заняла несколько месяцев, она была бы невозможна без тесного сотрудничества с коллегами из этих стран, которые уточняли и дополняли базу данных. Это позволило дополнить базу данных показателем численности населения городов (по состоянию на 2010 г. по данным национальных органов статистики).

\footnotetext{
${ }^{4}$ http://www.twinning.org
}

\section{Побратимские связи городов}

\section{Причерноморья: гипотезы и результаты}

База данных (табл. 2) включает информацию по 99 городам с численностью население 10 тыс. чел. и более: самый маленький город - Бюйюкионкале (10 072 чел.), самый большой - Истанбул (13 млн чел.); оба они находятся в Турции. Кроме Истанбула в базу включены также три города-миллионера (Донецк, Одесса и Ростов-на-Дону) и четыре города с населением более 500 тыс. чел. (Николаев, Гебзе, Краснодар и Запорожье). База данных включает 599 побратимских связей городов из 73 различных стран мира. Они были установлены в период между 1944 и 2013 гг., для 76\% из них установлены точные даты подписания соответствующего соглашения. Для изучения базы данных было выдвинуто несколько г и п о т е 3, изложенных ниже.

\section{1) Пропорционально ли количество побра-} тимских связей между городами их населению?

Исследования городов показывают, что закон ранг - размер позволяет объяснить место городов в иерархии в соответствии с их населением. Поэтому можно сделать предположение - чем больше в городе населения, тем больше у него городов-побратимов? Истанбул - город мирового значения с населением в десять раз больше, чем в Ростовена-Дону (второй по людности город в Причерноморье). На Истанбул приходится 10\% всех побратимских связей городов региона. Таким образом, на первых порах, мы его исключили из нашего анализа.

Модель линейной регрессии (рис. 1) без Истанбула показывает, что лишь менее $40 \%$ всех побратимских связей городов можно объяснить пропорциональной связью между числом городов-побратимов и численностью населения города $\left(\mathrm{R}^{2}=0,38\right)$.

Среди городов с населением более 500 тыс. чел., только Донецк соответствует этой модели. Одесса, которая находится в правом верхнем углу 
графика (рис. 1), имеет количество городов-побратимов намного больше, чем следовало ожидать, исходя из её численности населения: у неё 37 городовпобратимов, что на треть больше, чем у Донецка, численность населения которого ненамного больше.

Другие города России, Украины и Турции (Ростов-на-Дону, Краснодар, Николаев, Запорожье, Гебзе) имеют городов-побратимов меньше, чем следовало ожидать, исходя из данной модели. Это указывает на незавершённость процесса их интернационализации.

2) Какова сила влияния распада социалистической системы?

Следует заметить, что на открытие городов Причерноморья для международных связей, в т.ч. с городами-побратимами, серьёзным образом повлияли изменения в политическом строе в 1989 г. Болгарии и Румынии и в 1991 г. в странах бывшего СССР. В 90-е гг. XX ст. произошло становление многополярного мира, в котором Причерно-

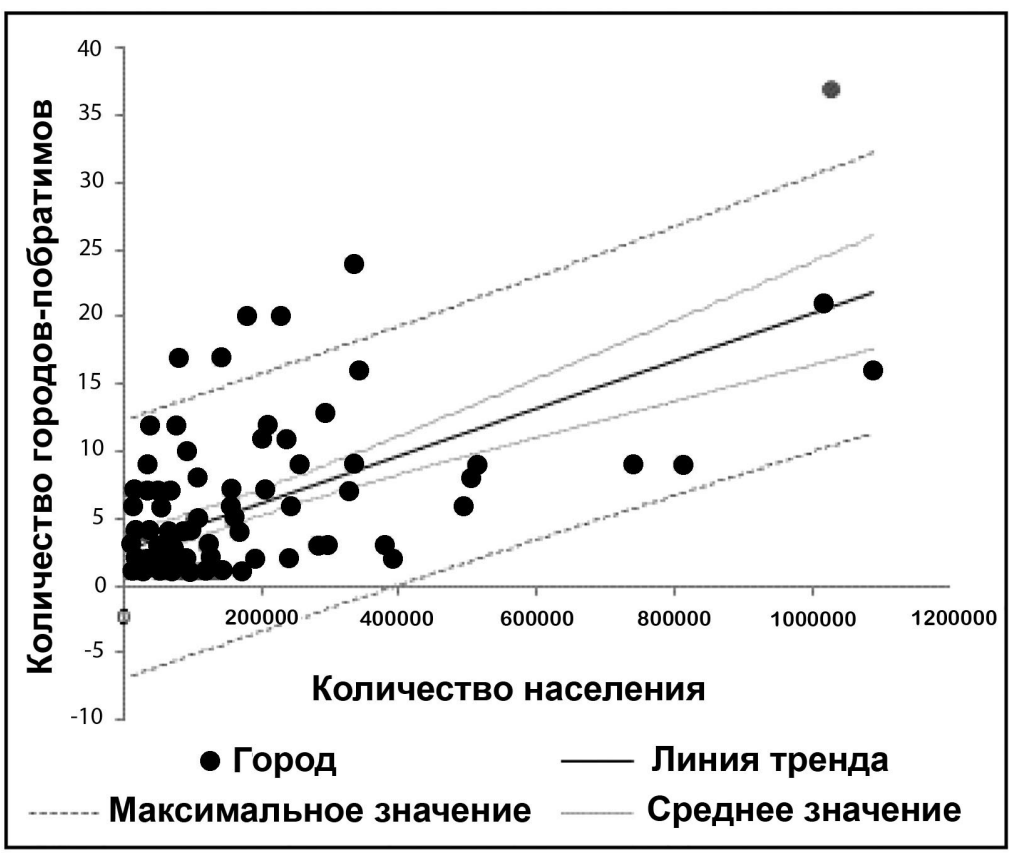

Рисунок 1. Связь между численностью населения и количеством городов-побратимов городов Причерноморья

Составлено на основе базы данных городов-побратимов. морье стало перекрестком между Азией, Европой и Ближним Востоком. Это чётко прослеживается на графике, показывающем изменение количества городов-побратимов во времени (рис.2). Их количество сильно увеличилось с конца 80-х гг. ХХ ст. В нач. XXI ст. видно существенное развитие побратимского движения в регионе.

Геополитические изменения прямо сказываются на географии побратимских связей городов Причерноморья. До 1990 г. они были обращены в направлении стран Западной Европы, в особенности стран, которые вели активную политику в данном вопросе (например, Франция и Германия). В 1990 г. наметилась тенденция к заключению новых соглашений о партнерстве между городами в пределах региона, что повлекло за собой всплеск таких связей между городами стран-соседей. Также видно возвращение геополитического интереса к Причерноморью со стороны США, России, Турции и Китая, которые вышли в лидеры по установлению побратимских связей городов. На первом месте остаётся объединенная Германия, которая принимает активное участие в развитии сотрудничества со странами бывшего социалистического лагеря.

Увеличение числа городов-побратимов сопровождалось ростом их географического разнообразия в начале XXI ст. Новые побратимские связи были установлены не только между городами прибрежных стран Чёрного моря (Россия, Болгария, Турция), но и городами стран Средиземноморья (Италия, Греция, Марокко, Израиль), или же в других регионах мира (Китай, Мексика, Иран).

В последнем случае большие портовые города заключали побратимские соглашения с городамипортами Причерноморья.

3) Какова роль пространственной близости?

Следует полагать, что в стратегиях побратимского движения определённую роль играет пространственная близость между городами.

Детальный анализ международных побратимских связей городов Причерноморья показал, что существуют определённые нюансы в данном вопpoce.

По ко ли ч е с т в у го род о в - п б т и м о в за весь период изучения Россия и Турция являются лидерами (соответственно 63 и 36). Это объясняется двумя фактами: их геополитическим и экономическим значением в регионе и их демографическим «весом» в рамках городского населения в Причерноморье. Следующее место занимает Болгария (43 города-побратима). Отчасти это объясняется высокой долей в таких связях побратимских отношений между турецкими и болгарскими городами, в которых значительная доля турецкого населения.

Группа из четырёх стран (около 30 городов-побратимов) включает Украину, Италию, Германию и Грецию. Три последние европейские страны с давней и развитой городской культурой активно участвуют в побратимском движении городов. В случае Греции укажем на её исторически важное значение для Причерноморья в античный период. Роль Украины можно объяснить демографическим «весом» городского населения. 


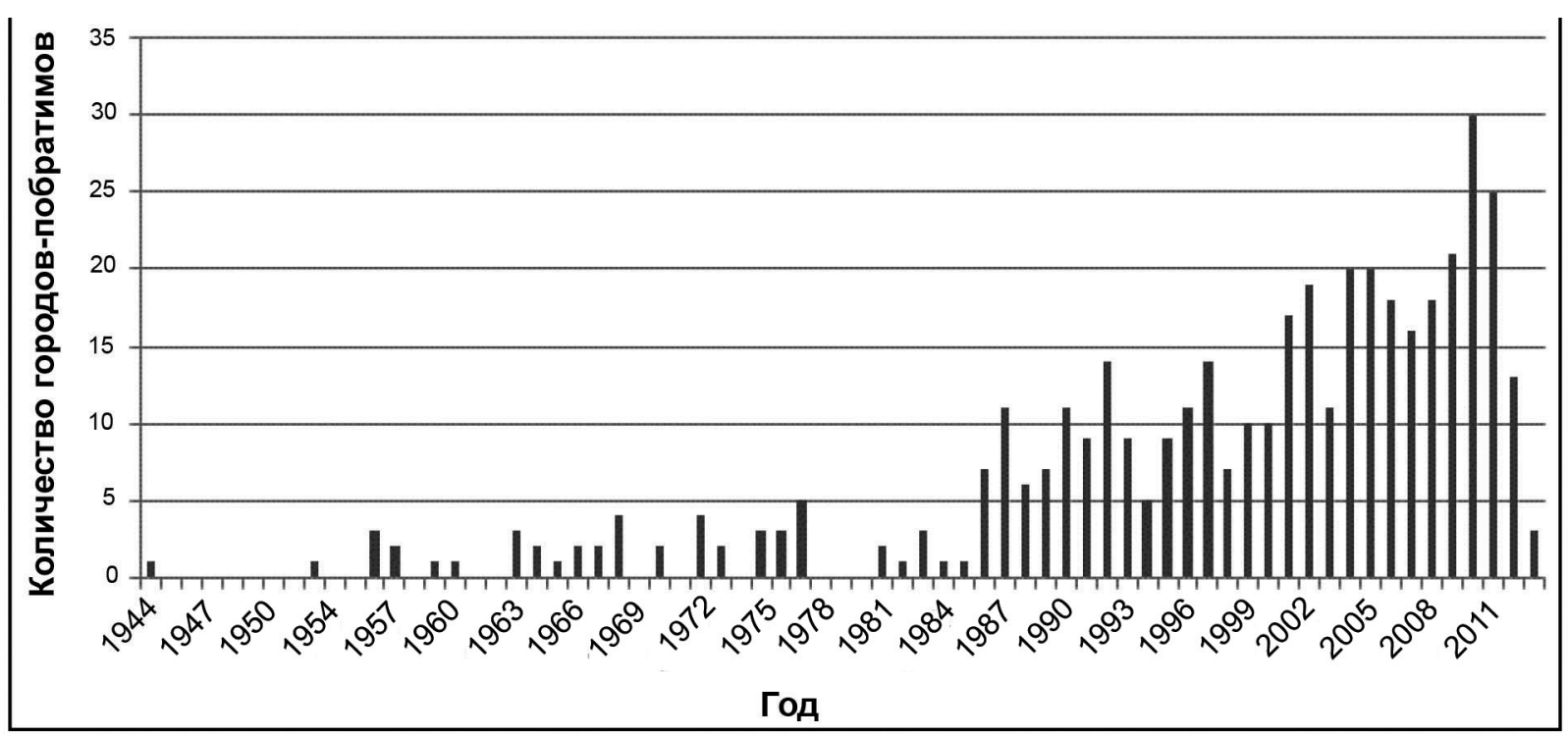

Рисунок 2. Количество городов-побратимов в Причерноморье, 1944 - 2013 гг.

Составлено на основе базы данных городов-побратимов

И, наконец, на восьмом и девятом местах находятся Соединенные Штаты Америки (26 городов-побратимов) и Китайская Народная Республика (21 город-побратим), что указывает на международную открытость городов Причерноморья - крупнейшие города-порты в этих странах являются основными городами-партнёрами в побратимском движении.

В общем, побратимские связи городов Причерноморья приблизительно одинаково разделены между шестью прибрежными государствами (207 городов-побратимов или же 34\%) и европейскими странами (ЕС-25, Швейцария и Норвегия), а на другие страны мира приходится 185 городовпобратимов (32\% от их общего числа).

Таким образом, можно сказать, что в Причерноморье существуют две главные тенденции - внутренней регионализации, что проявляется в усилении сотрудничества между городами на берегах Чёрного моря, и всё большей открытости к международныл связям с городами на других континентах. Тропизм Европы можно объяснить тем, что две страны (Болгария и Румыния) стали членами ЕС в 2007 г., а Турция является страной-кандидатом в его члены. Эта политика играла и играет существенную роль в развитии побратимских связей между европейскими городами. Европейские организации также политически и финансово поддерживают подобные инициативы.

Ге ографич еско е распреде ле ни е побратимских связей показало, что установление таких связей между городами, размещёнными на разных берегах Чёрного моря, немногочисленно (15 городов-побратимов).

Болгария и Румыния, как и следовало ожидать, предпочитают такие связи преимущественно с городами стран Европы.
Украинские города устанавливают побратимские связи преимущественно с городами в соседних причерноморских странах (на Балканах, Кавказе, южном берегу Средиземного моря) или же со странами Европы. Из трех городов-побратимов Горловки два находятся в США.

Точно так же поступают города России.

В Грузии побратимские связи между городами разделились между Европой и непосредственными странами-соседями в Причерноморье, единственный город-побратим вне этого ареала имеет Зугдиди с Колумбусом в США.

Турция имеет наиболее разнообразную географическую панораму побратимских связей городов. На один только Истанбул приходится 10\% из них, при этом треть таких связей с азиатскими городами приходится на основные порты в Китае, Малайзии, Республике Корея и Японии. Интернационализация этого портового города - мирового перекрёстка, очевидна. Другие важные турецкие порты на берегу Чёрного моря также ориентированы на Азию - Иран и Китай для Трабзона, Иран и Япония для Гиресуна, Самсун имеет немного более европейскую ориентацию (Киль в Германии, Кольмар в Швеции и Искеле на Кипре), а также побратимские связи с Новороссийском. С этим городом его связывает газопровод.

Наконец, анализ побратимских связей крупнейших портовых городов показывает, что у них весьма отличная с те пень и н те рн ц и он ал и з а ци и . Одесса, второй город после Истанбула по количеству городов-побратимов (37), имеет населения в десять раз меньше. Из 37 её городов-побратимов 28 большие города-порты мира на всех континентах (Ванкувер, Вальпараисо, Циндао, Александрия, Колката, Хайфа, Йокогама и другие), и с некоторыми из них они установлены уже очень давно (с 1957 г. с Оулу в Финляндии и с Ливерпу- 
лем в Великобритании). В 90-е гг. ХХ ст. этот город развил побратимские связи с городами-столицами государств (Минск, Москва, Никосия, Вена и Ереван), что он не мог сделать в советский период, исходя из существующей иерархии городов в установлении побратимских связей.

Другой город-миллионер по численности населения, Ростов-на-Дону, имеет совершенно иной профиль городов-побратимов. У этого города всего 16 городов-побратимов, из них лишь пять портовые города (Анталия в Турции, Глазго в Великобритании, Мобил в США, Одесса в Украине и Волос в Греции). Это можно объяснить тем, что Ростов-на-Дону является лишь одной из составных частей «системы пяти морей» России.

\section{Выводы}

Изучение побратимских связей городов Причерноморья позволило прийти к следующим выводам. Динамика их развития во времени указывает на активизацию в начале XXI ст. данной формы сотрудничества городов в рамках их интернационализации. Сотрудничество городов-побратимов является лишь частью многочисленных инициатив сотрудничества в Причерноморье, которое стало одним из главных регионов в изменившейся мировой геополитике.

Пространственная динамика побратимского движения имеет двойственное проявление в виде регионализации и глобализации. Регионализация побратимских связей городов способствовала их установлению между одной третью из городов прибрежных стран Чёрного моря. Руководство городов понимает важность установления и усиления международных городских сетей. Расширение контактов в рамках побратимского движения городов включает их в глобализацию - поэтому городапобратимы в Азии и Америке это, прежде всего, основные их портовые города. Африка, которая слабо вовлечена в глобализационные процессы, представлена лишь своим средиземноморским побережьем.

При этом остаётся ряд нерешённых вопросов, которые не нашли своего отражения в данном исследовании. Созданная база данных не содержит информации по поводу активности связей городовпобратимов, а также не позволяет установить, для решения каких вопросов имеет место сотрудничество между городами.

Эта информация позволяет провести более углублённый анализ. Также, в сотрудничестве с коллегами из причерноморских стран, необходимо установить посредством анкетирования представителей городских властей в самих городах причины мотивации принятия инициативы по заключению побратимского соглашения, формы и историю развития данных связей с целью выявления влияния на них геополитической, социальной и экономической эволюции этих стран.

\section{Лumepamypa}

1. Baldersheim H., Bucek J., Swianiewicz P. (2002). Mayors Learning across Borders: The International Networks of Municipalities in East-Central Europe. Reg. Fed. Stud., vol. 12, 1, 126-137.

2. Bontenbal M., Van Lindert P. (2009). Transnational city-to-city cooperation: Issues arising from theory and practice. Habitat Int., vol. 33, 2, 131-133.

3. Bucher K., Grillon N. (2008). Les jumelages stratégiques au service de la compétition entre les villes. Rev. Géographique Est, 48, 3-4.

4. Bussi M. (2009). Un monde en recomposition: géographie des coopérations territoriales. Mont-Saint-Aignan, Publications des Universités de Rouen et du Havre, DL.

5. Chombard-Gaudin C. (1992). Pour une histoire des villes et communes jumelées. Vingtième Siècle Rev. Hist., vol. 35, 1, 60-66.

6. Claeysen C. (1999). Les jumelages et l'Europe. Annu. Collectiv. Locales, vol. 19, 1, 125-138.

7. Clarke N. (2009). In what sense spaces of neoliberalism? The new localism, the new politics of scale, and town twinning. Polit. Geogr., vol. 28, 8, 496-507.

8. Clarke N. (2011). Globalising care? Town twinning in Britain since 1945. Geoforum, vol. 42, 1, 115-125.

9. Cremer R. D., De Bruin A., Dupuis A. (2001). International Sister-Cities: Bridging the Global-Local Divide. Am. J. Econ. Sociol., vol. $60,1,377-401$.

10. Drevet J.-F. (2010). Confrontation ou coopération dans le bassin de la mer noire? Conflu. Méditerranée, vol. 74, 3, 119-132.

11. Escach N., Vaudor L. Réseaux de villes et processus de recomposition des niveaux: le cas des villes baltiques. Cybergeo, 5 juillet 2014 .

12. Jayne M., Hubbard P., Bell D. (2013). Twin Cities: Territorial and Relational Geographies of Worldly Manchester. Urban Stud., vol. $50,2,239-254$.

13. Joenniemi P., Sergunin A. (2011). Another face of integration: city twinning in Europe. Res. J. Int. Stud., vol. 22, $120-131$.

14. Kuşku-Sönmez E. (2014). Regional cooperation in the Black Sea basin: what role for city diplomacy? Southeast Eur. Black Sea Stud., vol. $14,4,489-507$.

15. Moriconi-Ebrard F. Geopolis: pour comparer les villes du monde (Collection Villes). Paris, Anthropos: Diffusion Economica.

16. Serebrian O. Autour de la mer Noire: géopolitique de l'espace pontique. Perpignan, Artège Sciences humaines.

17. Sieca-Kozlowski E., Toumarkine A. Géopolitique de la mer Noire: Turquie et pays de l'ex-URSS. Paris, France, Karthala.

18. Swyngedouw E. (2004). Globalisation or glocalisation? Networks, territories and rescaling. Camb. Rev. Int. Aff., vol. 17, 1, 25-48.

19. Viltard Y. (2008). Conceptualiser la diplomatie des villes. Rev. Fr. Sci. Polit., vol. 58, 3, 511-533.

20. Vion A. (2002). Europe from the Bottom up: Town Twinning in France during the Cold War. Contemp. Eur. Hist., vol. 11, 4, 623-640.

21. Zelinsky W. (1991). The Twinning of the World: Sister Cities in Geographic and Historical Perspective. Ann. Assoc. Am. Geogr., vol. $81,1,1-31$. 